\title{
ANALYSING THE BIOACTIVE MAKEUP OF DEMINERALISED DENTINE MATRIX ON BONE MARROW MESENCHYMAL STEM CELLS FOR ENHANCED BONE REPAIR
}

\author{
S.J. Avery, L. Sadaghiani, A.J. Sloan and R.J. Waddington* \\ Oral and Biomedical Sciences, School of Dentistry / Cardiff Institute of Tissue Engineering and Repair, \\ Cardiff University, Cardiff, UK.
}

\begin{abstract}
Dentine matrix has proposed roles for directing mineralised tissue repair in dentine and bone; however, the range of bioactive components in dentine and specific biological effects on bone-derived mesenchymal stem cells (MSCs) in humans are less well understood. The aims of this study were to further elucidate the biological response of MSCs to demineralised dentine matrix (DDM) in enhancing wound repair responses and ascertain key contributing components. Dentine was obtained from human teeth and DDM proteins solubilised with ethylenediaminetetraacetic acid (EDTA). Bone marrow derived MSCs were commercially obtained. Cells with a more immature phenotype were then selected by preferential fibronectin adhesion (FN-BMMSCs) for use in subsequent in vitro assays. DDM at $10 \mu \mathrm{g} / \mathrm{mL}$ reduced cell expansion, attenuated apoptosis and was the minimal concentration capable of inducing osteoblastic differentiation. Enzyme-linked immunosorbent assay (ELISA) quantification of growth factors indicated physiological levels produced the above responses; transforming growth factor $\beta$ (TGF- $\beta 1$ ) was predominant (15.6 ng/mg DDM), with relatively lower concentrations of BMP-2, FGF, VEGF and PDGF (6.2-4.7 ng/mg DDM). Fractionation of growth factors from other DDM components by heparin affinity chromatography diminished osteogenic responses. Depletion of biglycan from DDM also attenuated osteogenic potency, which was partially rescued by the isolated biglycan. Decorin depletion from DDM had no influence on osteogenic potency. Collectively, these results demonstrate the potential of DDM for the delivery of physiological levels of growth factors for bone repair processes, and substantiate a role for biglycan as an additional adjuvant for driving osteogenic pathways.
\end{abstract}

Key words: Mesenchymal stem cells, dentine, growth factors, biglycan, decorin, cell expansion, osteoblast differentiation, migration, apoptosis.

* Address for correspondence: Professor Rachel Waddington, Oral and Biomedical Sciences, School of Dentistry, Heath Park, Cardiff University, Cardiff, CF14 4XY, UK.

Telephone: +44(0)2920742609 Email: waddingtonrj@cardiff.ac.uk

\section{Introduction}

A plethora of growth factors, such as various isoforms of transforming growth factor $\beta$ (TGF- $\beta$ ), bone morphogenetic proteins (BMPs), vascular endothelial growth factor (VEGF), fibroblast growth factors (FGF), platelet-derived growth factor (PDGF) and insulinlike growth factor (IGF) are widely implicated in directing the early events of osteogenesis (Dimitriou et al., 2005). These growth factors have all been identified to play crucial roles in promoting cell migration to the repair site, proliferation and differentiation of endogenous MSCs to form bone synthesising osteoblasts (Roberts and Rosenbaum, 2012), in addition to promoting angiogenesis (Geiger et al., 2005). Indeed, it is against background research of growth factor roles as isolated entities that BMP-2 and BMP-7, have both been approved for therapeutic use in clinical practice (Axelrad and Einhorn, 2009). However, problems exist related to toxicity of the supraphysiological doses required to evoke a stimulatory response. Resultantly, the true efficacy of clinical success is questioned due to the potential for stimulating ectopic bone formation and inflammation (Zara et al., 2011; Lee et al., 2011). These issues have partially been addressed through administering combinations of growth factors where lower dosage levels have demonstrated enhanced osteogenic bioactivity in vitro and in vivo compared to individual factors (Kanczler et al., 2010; Tachi et al., 2011; Simmons et al., 2004); strengthening evidence for the activities of multiple growth factors acting synergistically to deliver optimised signalling (Chen et al., 2010). 
Dentine is recognised to possess the capacity to undergo endogenous regeneration in response to carious injury, where demineralisation results in the dissolution of bioactive constituents within the matrix. These released bioactive factors stimulate resident dental pulp-derived stem cells (DPSCs) to differentiate into odontoblast-like cells, which secrete a reparative mineralised matrix that is comparable in structure to bone (Smith et al., 1995; Arana-Chavez and Massa, 2004). Due to the bioactive potential of dentine in vivo being limited to stimulating reparative responses within teeth, more recent studies have investigated the potential of demineralised dentine matrix (DDM) to stimulate bone repair. Placement of dentine in vivo has been reported to stimulate reparative bone formation in rabbit critical defects (Gomes et al., 2008) and in rat tooth sockets (de Oliveira et al., 2013). In vitro, DDM has been demonstrated to induce mineralisation and increased expression of bone forming markers of human DPSCs (Lee et al., 2015; Gonçalves et al., 2016; Liu et al., 2016) and murine bone marrow MSCs (BMMSCs) (Yu et al., 2014). Proteomic studies of human dentine have identified the presence of up to 289 different components, with TGF- $\beta 1$ identified as a prominent growth factor (Jágr et al., 2012; Chun et al., 2011; Park et al., 2009). Immuno-histochemical studies have also identified the additional presence of BMP-2 (Casagrande et al., 2010), vascular epidermal growth factor (VEGF) (Roberts-Clark and Smith, 2000) and IGF (Finkelman et al., 1990). Whilst the synergistic signalling activities of these growth factors are acknowledged in contributing to osteoblast differentiation and directing bone repair, there is an increasing recognition for contributions by other matrix constituents which are proposed to act to tether growth factors to the extracellular matrix and influence signalling activity. Members of the small leucine-rich proteoglycans (SLRPs), biglycan and decorin, are major constituents in dentine (Waddington et al., 2003a). These SLRPs have proposed roles in modulation of growth factor bioactivity and facilitating their sequestration within biological matrices, thereby protecting them from proteolysis, extending their extracellular half-life and regulating release to the cell (Baker et al., 2009). In addition, biglycan has been described to directly stimulate bone formation via dual signalling mechanisms of the BMP/TGF $\beta$ and the canonical Wnt/ $\beta$-catenin pathways and hence has been proposed as a promising therapeutic in bone related diseases involving defects in these pathways (Nikitovic et al., 2012; Nastase et al., 2012).

Both in vitro and in vivo studies have demonstrated an ability for dentine matrix components to drive mineralised tissue repair, and thus DDM may be regarded as a physiologically optimised bioactive matrix that is able to drive wound repair responses, and thus may have a therapeutic application for stimulating bone repair and regeneration. However, whilst the presence of prime growth factors with proposed roles in bone repair can presumed to be present, a fuller characterisation of the growth factor profile DDM contains still remains unknown. Further, the importance of other extracellular matrix components, such as the SLRPs, for synergistically enhancing growth factor activity has not previously been established as a key contributor to DDM's bioactivity. Using human derived tissue and cells, this study quantified the physiological growth factor levels in DDM able to evoke an osteogenic response, in addition to confirming the presence of biglycan and decorin. Bioactivity of DDM, including determining dose effects, was examined, in order to dissect its regulatory activity on key biological events that are prerequisite for successful bone repair; namely, MSC migration, promoting cell survival and regulating proliferation, osteoblast differentiation and deposition of a mineralised matrix. Through fractionation of growth factors and immuno-depletion of decorin and biglycan matrix components, the importance of these components for driving osteogenesis of human BMMSCs was evaluated.

\section{Materials and Methods}

Preparation of demineralised dentine matrix (DDM) Human teeth (representing healthy tissue from 10 molars, pre-molars, canines and incisors) were obtained from Cardiff University School of Dentistry "Toothbank," with patient informed consent in accordance with ethical approval granted by South East Wales Research Ethics Committee, (12/WA/0289). Enamel, cementum and soft tissues of the pulp and attached gingiva were dissected away and the remaining dentine (7.5 g) was powdered using a percussion mill cooled in liquid nitrogen. DDM was extracted from dentine powder using $7.5 \%$ EDTA $\mathrm{diNa}^{+}$, as previously described by Lee et al. (2015). Soluble extracts were recovered by centrifugation at $1,100 \times g$ for $10 \mathrm{~min}$, dialysed against double distilled water (ddwater) at $4{ }^{\circ} \mathrm{C}$, lyophilised and stored at $-20{ }^{\circ} \mathrm{C}$ (total of $0.5 \mathrm{~g}$ DDM produced for all subsequent experiments described). DDM aliquots were reconstituted to $1 \mathrm{mg} / \mathrm{mL}$ in tris-buffered saline (TBS) and sterile filtered through a $0.22 \mu \mathrm{M}$ filter. Protein concentration was determined using a Pierce ${ }^{\circledR}$ BCA Assay Kit (Thermo Fisher Scientific, Newport, UK).

\section{Characterisation of DDM}

SDS-PAGE and Western blot analysis

DDM samples were separated by electrophoresis using 4-15\% Mini-PROTEAN ${ }^{\circledR}$ TGX pre-cast gels (Bio-Rad, Hemel Hempstead, Herts, UK) with running buffer $25 \mathrm{mM}$ Tris, $192 \mathrm{mM}$ glycine, $0.1 \%$ SDS, pH 8.3, at 200 V. A Silver Stain Plus ${ }^{\mathrm{TM}}$ kit (BioRad, Hemel Hempstead, Herts, UK) was used to visualise protein. Western blot analysis of separated protein components were conducted as described by Sadaghiani et al. (2016). Details of antibodies 
Table 1. Details of primary antibodies, corresponding secondary antibodies and respective blocking peptides (used to confirm specificity of antibody binding) for immuno detection in Western blot analysis and immuno-precipitation protocols. (All antibodies and blocking peptides from Santa Cruz Biotechnology Inc, Santa Cruz, CA, USA; N/A not available).

\begin{tabular}{|l|l|l|l|l|}
\hline $\begin{array}{l}\text { Primary antibody } \\
(\mathbf{A b})\end{array}$ & $\begin{array}{l}\text { Primary Ab } \\
\text { Dilution }\end{array}$ & Secondary Ab & $\begin{array}{l}\text { Secondary Ab } \\
\text { dilution }\end{array}$ & Blocking peptide \\
\hline TGF- $\beta 1(\mathrm{~V})$ & $1: 200$ & Anti-rabbit HRP (sc-2030)- & $1: 25,000$ & TGF- $\beta 1(\mathrm{~V})$ \\
\hline BMP-2 (N-14) & $1: 500$ & Anti-goat HRP (sc-2020) & $1: 50,000$ & BMP-2 (N-14) \\
\hline VEFG (A-20) & $1: 200$ & Anti-rabbit HRP (sc-2030) & $1: 25,000$ & VEFG (A-20) \\
\hline Biglycan (L-15) & $1: 500$ & Anti-goat HRP (sc-2020) & $1: 50,000$ & N/A \\
\hline Decorin (N-15) & $1: 300$ & Anti-goat HRP (sc-2020) & $1: 50,000$ & N/A \\
\hline
\end{tabular}

and blocking peptides are described in Table 1. Negative controls were performed by incubating primary antibodies with $10 \times$ excess of respective blocking peptide for $1 \mathrm{~h}$ prior to incubation with the membrane.

\section{ELISA}

DDM was reconstituted in $\alpha$-MEM (containing ribonucleosides and deoxyribinucleosides) (Thermo Fisher Scientific, Newport, UK) and growth factors quantified using the following commercially available kits; Human TGF- $\beta 1$ Platinum ELISA kit (eBioscience, Altrincham, Ches., UK); Human IGF-1 Quantikine $^{\circledR}$ ELISA kit (R\&D Systems, Abingdon, Oxon, UK); Human BMP-4 and Human BMP-7 ELISA kits respectively (Sigma-Aldrich, Poole, UK); BMP-2, VEGF, PDGF-BB and FGF-2 using respective Human Mini ELISA kits (PeproTech, London, UK). Assays were performed in triplicate on three separate occasions (two separate occasions for BMP-4 and BMP-7 where lack of material prevented analysis for detection of low growth factor levels).

\section{Fractionation of DDM}

\section{Heparin affinity chromatography}

DDM was reconstituted in binding buffer $(0.01 \mathrm{M}$ Tris- $\mathrm{HCl} / 0.1 \mathrm{M} \mathrm{NaCl}, \mathrm{pH}$ 7, in $18.2 \mathrm{M} \Omega$ water) and passed through a sterile $0.22 \mu \mathrm{M}$ syringe filter. Protein concentration was determined. $1.8 \mathrm{mg}$ was applied to a Heparin HiTrap column, incorporated into an AKTA Purifier FPLC system (both GE Healthcare Life Sciences, Amersham, Bucks, UK) over $15 \mathrm{~mL}$ at $1 \mathrm{~mL} / \mathrm{min}$. Flow through eluent (FT) was collected as one fraction. Bound DDM components were eluted by application of a linear $0.1-3 \mathrm{M} \mathrm{NaCl}$ gradient, over 12 column volumes at $2 \mathrm{~mL} / \mathrm{min}$. $2.5 \mathrm{~mL}$ fractions were collected and subsequently pooled into EL1 and EL2, based on the $280 \mathrm{~nm}$ absorbance profile. Pooled fractions were dialysed against ddwater, lyophilised and re-suspended in TBS. Protein concentration in each fraction was determined and expressed as a percentage of original protein added to the column. TGF $\beta-1$ and BMP-2 concentrations in each fraction were determined by ELISA and the presence of biglycan and decorin by Western blot analysis.

Immuno-precipitation of decorin and biglycan from DDM Immunoprecipitation was achieved using a Pierce ${ }^{\circledR}$ Crosslink IP Kit (Thermo Fisher Scientific, Newport,
UK), according to manufacturer's protocol. Columns were cross-linked with either $10 \mu \mathrm{g}$ biglycan (sc-27936) or decorin (sc-22613) antibody (both from Santa Cruz Biotechnology Inc, Santa Cruz, CA, USA). $700 \mu \mathrm{g}$ DDM was applied to respective antibody-loaded columns and incubated overnight. Biglycan / decorin depleted DDM, followed by bound material, was eluted from the column following manufacturer's protocol. Eluents were dialysed against ddwater, lyophilised and re-suspended in TBS. Protein concentration was determined and expressed as a percentage of DDM applied to the column.

\section{Cell source, preparation and culture}

BMMSCs were obtained commercially (Lonza, Slough, UK; from a 30-year-old male donor). Cells were seeded at 5,000 cells $/ \mathrm{cm}^{2}$ and cultured in basal medium $(\alpha-$-MEM containing ribonucleosides and deoxyribinucleosides (Thermo Fisher Scientific, Newport, UK), 10 \% foetal calf serum (Invitrogen, Thermo Fisher Scientific, Newport, UK), $100 \mu \mathrm{M}$ L-ascorbic-2-phosphate (Sigma-Aldrich, Poole, UK), $1 \times$ Antibiotic/Antimycotic (Sigma-Aldrich, Poole, UK)), $37^{\circ} \mathrm{C}, 5 \% \mathrm{CO}_{2}$. At $70-80 \%$ confluence, a single cell suspension was produced using Accutase (PAA Laboratories $\mathrm{GmbH}$, Pasching, Austria) and immature cells were selected by preferential adherence to fibronectin (human plasma; Sigma-Aldrich, Poole, UK) over $20 \mathrm{~min}$, as described previously by Lee $\mathrm{et} \mathrm{al}$. (2015). Preferential selection of fibronectin-adherent BMMSCs was performed to increase the homogeneity of the cell population and reduce the effects of donor variability when replicating these experiments. Fibronectin adherent cells (FN-BMMSCs) and BMMSCs were culture expanded in the above media.

\section{MSC characterisation}

Population doublings (PDs)

At each passage, cell counts were determined and PDs calculated, proportional to cell numbers initially seeded:

$P D=\frac{\log _{10} \text { total cell count obtained }-\log _{10} \text { total cell count reseeded }}{\log _{10} 2}$

Cells were reseeded at 4,000 cells $/ \mathrm{cm}^{2}$.

Reverse Transcription PCR

BMMSCs and FN-BMMSCs were cultured until 90-100\% confluent. RNA was extracted using an 
RNeasy kit (Qiagen, Hilden, Germany). cDNA was synthesised from $1 \mu \mathrm{g}$ of total RNA using the M-MLV reverse transcriptase system (Promega, Southampton, UK, ), amplified within a Thermal Cycler at $70{ }^{\circ} \mathrm{C}$ for 5 min. Total human RNA (Clontech, Saint-Germain-enLaye, France) or nuclease free water to replace sample RNA served as respective positive or negative controls. Expression of purported mesenchymal, embryonic and haematopoietic stem cell markers was examined using a standard RT-PCR protocol with forward and reverse primers, detailed in Table 2 , and the following cycling conditions: 1 initial denaturation at $95{ }^{\circ} \mathrm{C}$, $4 \mathrm{~min}$; 35 cycles of $95^{\circ} \mathrm{C}, 1 \mathrm{~min}$ and $72{ }^{\circ} \mathrm{C}, 1 \mathrm{~min}$; 1 final extension at $72{ }^{\circ} \mathrm{C}, 10 \mathrm{~min}$. RT-PCR products were separated on $2 \%$ agarose/ethidium bromide gels and visualised by UV light.

\section{$\beta$-galactosidase staining}

MSCs, cultured to suspected senescence as indicated by $\mathrm{PD}<0.5$, and pre-senescent cells were analysed. $\beta$-galactosidase staining was performed using a Senescent Cells Histochemical Staining Kit (SigmaAldrich, Poole, UK).

\section{Culture of FN-BMMSCs in the presence of DDM} and fractions

For fractionated DDM samples, protein concentration added to culture media was adjusted to represent the percentage of total DDM as calculated above (i.e. percentage of $10 \mu \mathrm{g} / \mathrm{mL}$ ).

\section{MTT Cell expansion assay}

FN-BMSCs (10 PDs) were seeded into 96-well plates at 4,000 cells $/ \mathrm{cm}^{2}$ in $5 \%$ foetal bovine serum (FBS) culture medium, supplemented with $0-10 \mu \mathrm{g} / \mathrm{mL}$ DDM or relative proportion of fractionated sample. Cell expansion was determined using a MTT assay (Sigma-Aldrich, Poole, UK) over a 0-96 h culture period.

\section{Caspase apoptosis assay}

FN-BMSCs (14.5 PD) were seeded into white-walled, optically clear 96 -well plates at 4,000 cells $/ \mathrm{cm}^{2}$ in $10 \%$ FBS culture medium supplemented with $0-10 \mu \mathrm{g} / \mathrm{mL}$ DDM. Apoptotic cells were detected over $48 \mathrm{~h}$ using a Caspase-Glo ${ }^{\circledR}$ 3/7 Assay (Promega, Madison, WI, USA).

\section{Cellular migration assay}

Cell migration through collagen was measured using Boyden chamber assay system. $52.54 \mu \mathrm{L}$ type 1 collagen (supplied $3.7 \mathrm{mg} / \mathrm{mL}$ in $0.02 \mathrm{~N}$ acetic acid; Sigma-Aldrich, Poole, UK) was added to $1 \mathrm{~mL}$ $\alpha$-MEM and neutralised with $10.58 \mu \mathrm{L} 0.1 \mathrm{~N} \mathrm{NaOH}$. The uppermost surface of 24-well tissue culture inserts ( $8 \mu \mathrm{M}$ pores; Greiner Bio-One, Stonehouse,

Table 2. Details of forward and reverse primer sequences and cycling conditions used for RT-PCR and qPCR. GAPDH was used as reference gene.

\begin{tabular}{|c|c|c|c|c|}
\hline $\begin{array}{l}\text { Gene } \\
\text { product }\end{array}$ & Primer sequence: $5^{\prime}-3^{\prime}$ & $\begin{array}{l}\text { Annealing } \\
\text { temperature } \\
\left({ }^{\circ} \mathrm{C}\right)\end{array}$ & $\begin{array}{l}\text { Product } \\
\text { length } \\
\text { (bp) }\end{array}$ & Application \\
\hline GAPDH & $\begin{array}{l}\text { F: TTCTTTTGCGTCGCCAGCCGA } \\
\text { R: GTGACCAGGCGCCCAATACGA }\end{array}$ & 55 & 96 & $\begin{array}{l}\text { RT PCR / qPCR } \\
\text { Housekeeping gene }\end{array}$ \\
\hline CD105 & $\begin{array}{l}\text { F: GAAACAGTCCATTGTGACCTTCAG } \\
\text { R: GATGGCAGCTCTGTGGTGTTGACC }\end{array}$ & 55 & 344 & $\begin{array}{l}\text { RT PCR } \\
\text { MSC marker }\end{array}$ \\
\hline CD90 & $\begin{array}{l}\text { F: ATGAACCTGGCCATCAGCATCG } \\
\text { R: CACGAGGTGTTCTGAGCCAGCA }\end{array}$ & 55 & 425 & $\begin{array}{l}\text { RT PCR } \\
\text { MSC marker }\end{array}$ \\
\hline CD73 & $\begin{array}{l}\text { F: GTCGCGAACTTGCGCCTGGCCGCCAAG } \\
\text { R: TGCAGCGGCTGGCGTTGACGCACTTGC }\end{array}$ & 55 & 352 & $\begin{array}{l}\text { RT PCR } \\
\text { MSC marker }\end{array}$ \\
\hline CD146 & $\begin{array}{l}\text { F: TGTGTAGGGAGGAACGGGTA } \\
\text { R: TGGGACGACTGAATGTGGAC }\end{array}$ & 55 & 101 & $\begin{array}{l}\text { RT PCR } \\
\text { MSC marker }\end{array}$ \\
\hline CD34 & $\begin{array}{l}\text { F: GCTTTGCTTGCTGAGTTTGC } \\
\text { R: CCATGTTGAGACACAGGGTGC }\end{array}$ & 55 & 180 & $\begin{array}{l}\text { RT PCR } \\
\text { Haemopoietic stem cell marker }\end{array}$ \\
\hline CD45 & $\begin{array}{l}\text { F: CCCCACTGATGCCTACCTTA } \\
\text { R: ATGCACCTCATTGTTTGTGC }\end{array}$ & 55 & 238 & $\begin{array}{l}\text { RT PCR } \\
\text { Haemopoietic stem cell marker }\end{array}$ \\
\hline Oct4 & $\begin{array}{l}\text { F: GGTGGAGAGCAACTCCGAT } \\
\text { R: ATGGTCGTTTGGCTGAATACC }\end{array}$ & 55 & 246 & $\begin{array}{l}\text { RT PCR } \\
\text { Embryonic MSC marker }\end{array}$ \\
\hline Nanog & $\begin{array}{l}\text { F: AGGTCCCGGTCAAGAAACAG } \\
\text { R: CCCTGCGTCACACCATTG } \\
\end{array}$ & 55 & 235 & $\begin{array}{l}\text { RT PCR } \\
\text { Embryonic MSC marker }\end{array}$ \\
\hline RunX2 & $\begin{array}{l}\text { F: GGTTAATCTCCGCAGGTCACT } \\
\text { R: CCСTCTGTTGTAAATACTGCTTGC }\end{array}$ & 55 & 80 & $\begin{array}{l}\text { qPCR / RT PCR } \\
\text { Early osteoblast differentiation marker }\end{array}$ \\
\hline $\begin{array}{l}\mathrm{CO}- \\
\mathrm{L} 1 \mathrm{~A} 1\end{array}$ & $\begin{array}{l}\text { F: TGCTGTTGGTGCTAAGGG } \\
\text { R: GCAATACCAGGAGCACCATTG }\end{array}$ & 55 & 177 & $\begin{array}{l}\mathrm{qPCR} \\
\text { Matrix deposition marker }\end{array}$ \\
\hline OC & $\begin{array}{l}\text { F: GGCAGCGAGGTAGTGAAGAG } \\
\text { R: CTCACACACСТСССТССТ }\end{array}$ & 55 & 102 & $\begin{array}{l}\text { qPCR } \\
\text { Late osteoblast differentiation marker }\end{array}$ \\
\hline
\end{tabular}


Glos., UK) were coated with $10 \mu \mathrm{g}$ of type I collagen in solution, left to solidify at $37^{\circ} \mathrm{C}$ overnight and then air dried for $1 \mathrm{~h}$ at room temperature. FN-BMMSCs (12.6 PDs) were serum starved for $24 \mathrm{~h}$ and re-seeded at 10,000 cells $/ \mathrm{cm}^{2}$ in $200 \mu \mathrm{L} /$ well in serum-free culture medium onto the collagen-coated inserts. Inserts were placed into the lower chamber containing $600 \mu \mathrm{L} /$ well serum-free medium supplemented with $0-10 \mu \mathrm{g} / \mathrm{mL}$ DDM and incubated at $37{ }^{\circ} \mathrm{C}, 5 \% \mathrm{CO}_{2}$. After $20 \mathrm{~h}$ medium in the lower compartment was replaced with $450 \mu \mathrm{L}$ of serum-free culture medium containing $8 \mu \mathrm{M}$ Calcein-AM (Sigma-Aldrich, Poole, UK) and incubated at $37^{\circ} \mathrm{C}$ for $45 \mathrm{~min}$. This culture medium was then replaced with $500 \mu \mathrm{L}$ of $0.05 \%$ TrypsinEDTA (Sigma-Aldrich, Poole, UK) to detach cells over $10 \mathrm{~min}$ at $37^{\circ} \mathrm{C} .200 \mu \mathrm{L}$ of Trypsin solution was removed from each well and fluorescence read using $485 \mathrm{~nm}$ excitation/520 nm emission wavelengths.

\section{Osteogenic differentiation}

FN- BMMSCs (15-17 PD) were seeded at 10,000 cells $/ \mathrm{cm}^{2}$ and cultured in $\alpha$-MEM basal medium supplemented with $0-10 \mu \mathrm{g} / \mathrm{mL}$ DDM or equivalent fractionated sample at $37^{\circ} \mathrm{C}, 5 \% \mathrm{CO}_{2}$. Basal medium supplemented with $10 \mathrm{mM} \beta$-glycerophosphate and $10 \mathrm{nM}$ dexamethasone (both Sigma-Aldrich, Poole, UK) provided a positive osteogenic control.

\section{Alizarin Red Staining}

After $28 \mathrm{~d}$, cultured cells were washed twice with PBS, fixed in $10 \%$ formaldehyde (Sigma-Aldrich, Poole, UK), $30 \mathrm{~min}$, washed twice in PBS and stained with $2 \%(w / v)$ Alizarin Red S (pH 4.1-4.3) (SigmaAldrich, Poole, UK) for $20 \mathrm{~min}$. Cells were washed with ddwater and digital images captured with a light microscope.

\section{Quantitative real-time PCR}

Gene expression for osteogenic related markers RunX2, osteocalcin (OC) and Col1A1 was assessed. RNA was extracted from cultured cells and converted to cDNA by reverse transcription as described above. For qPCR analysis, cDNA was added to primer sets (Table 2) and PrecisionFAST Master Mix pre-mixed
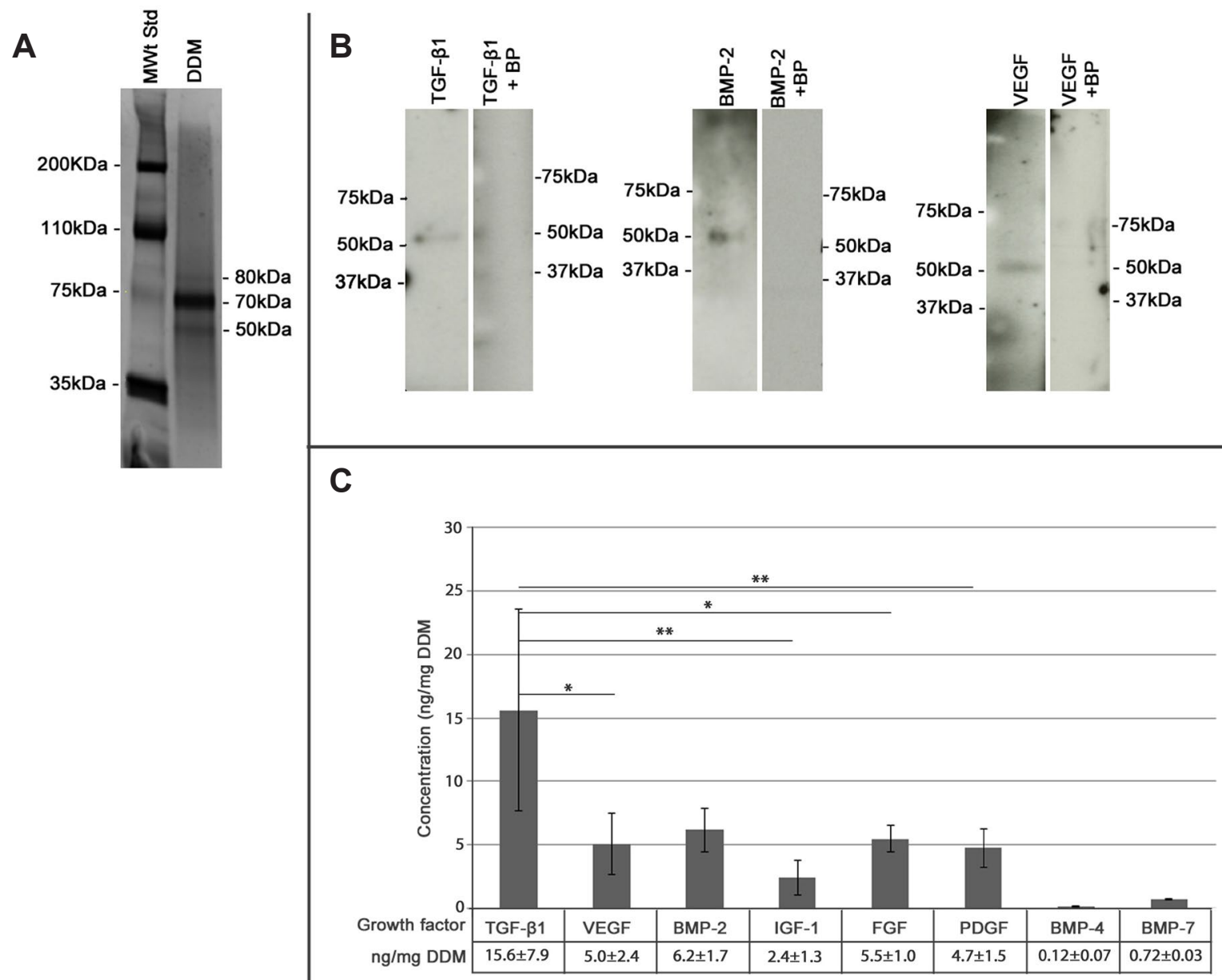

Fig. 1. Assessment of growth factor composition present in DDM. (A) Separation of DDM by SDS PAGE with strong silver staining protein bands evident at 80,70 and $50 \mathrm{kDa}$. (B) Immuno-detection of TGF- $\beta 1$, BMP-2 and VEGF within DDM, with all detected within the $50 \mathrm{kDa}$ protein band. (C) Quantification of growth factors present in DDM using respective ELISA assays. From standard curves, growth factors were calculated to be present within the DDM in low ng to $\mathrm{pg} / \mathrm{mL}$ concentration range, with TGF- $\beta 1$ the most abundant growth factor. ELISAs were performed in triplicate on three separate occasions ${ }^{*}=p<0.05,{ }^{* *}=$ $p<0.01,{ }^{* * *}=p<0.001$. 
with SYBR green (Primer Design Ltd, Eastleigh, Hamps, UK). qPCR was performed using QuantStudio ${ }^{\mathrm{TM}} 6$ Flex Real-Time PCR System (Thermo Fisher Scientific, Newport, UK) with the following cycling reaction conditions: 1 initial denaturation at $95{ }^{\circ} \mathrm{C}$ for $20 \mathrm{~s}$; 40 cycles of denaturation for $1 \mathrm{~s}$, annealing for $20 \mathrm{~s}$. GAPDH was the internal reference gene.

\section{Statistical analysis}

For all assays performed above, triplicate samples were analysed for each sample group examined, and assays were repeated on three separate occasions. Statistical analyses to determine analysis of variance between sample groups were performed by OneWay ANOVA with a post-hoc Tukey test using Instat GraphPad software (GraphPad, La Jolla, CA, USA).

\section{Results}

\section{Quantification of growths factors in DDM}

Separation of DDM by SDS PAGE indicated the presence of protein material from $250 \mathrm{kDa}$ to $6 \mathrm{kDa}$, with strong bands at approximately $80 \mathrm{kDa}$, $70 \mathrm{kDa}$ and $50 \mathrm{kDa}$ (Fig. 1A). Subsequent Western blot analysis of separated gels, indicated immunopositivity for TFG- $\beta 1$, BMP-2 and VEGF at $50 \mathrm{kDa}$. Pre-incubation of the primary antibody with their respective blocking peptide confirmed specificity for the antibody used (Fig. 1B). ELISA quantification of growth factors revealed TGF- $\beta 1$ as the most abundant growth factor $(15.6 \pm 7.9 \mathrm{ng} / \mathrm{mg} \mathrm{DDM} ; n=3)$. FGF2, BMP-2, PDGF, VEGF and IGF-1 demonstrated intermediate abundance $(6.2-2.4 \mathrm{ng} / \mathrm{mg} ; n=3)$. BMP-4 and BMP-7 represented the lowest abundant factors (approximately 120-72 pg/mg DDM; $n=2$ as insufficient material available to accurately detect growth factors present at pg levels).

\section{Isolation of immature FN-BMMSC cells from BMMSCs}

Cells used in this study were selected for adherence to fibronectin to isolate the more immature MSC population (FN-BMMSCs; Lee et al., 2015; Jones and Watt, 1993), to reduce heterogeneity of the cell population and increase potential for reproducibility on these commercially derived cells, which would likely be obtained from different donors. Both BMMSCs and selected FN-BMMSCs expressed purported MSC markers (Reviewed by Mafi et al.,
A
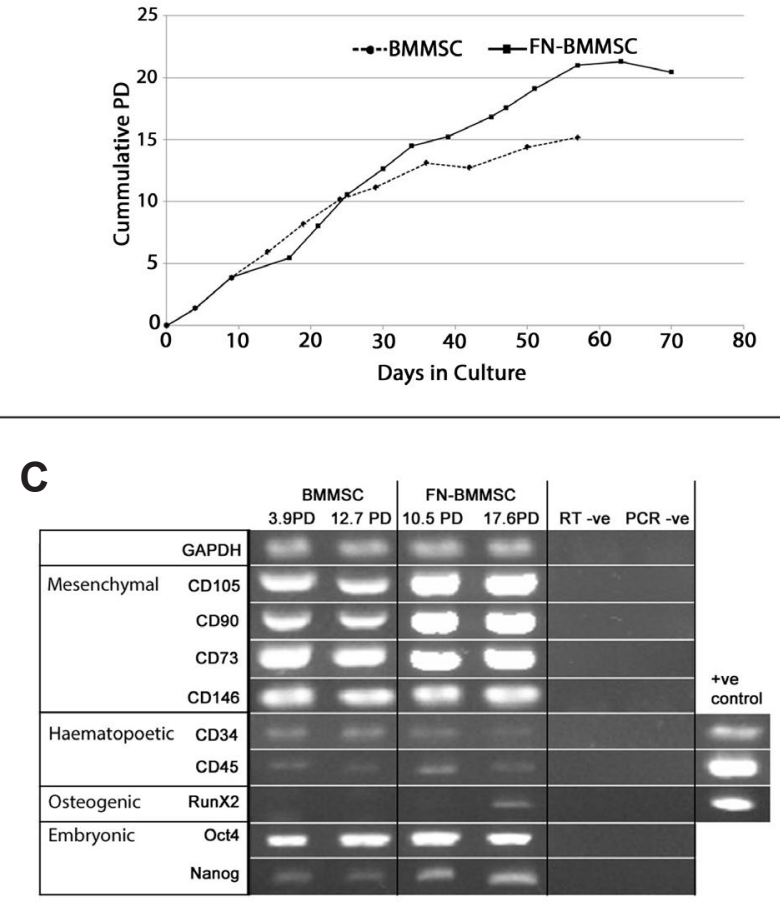

B

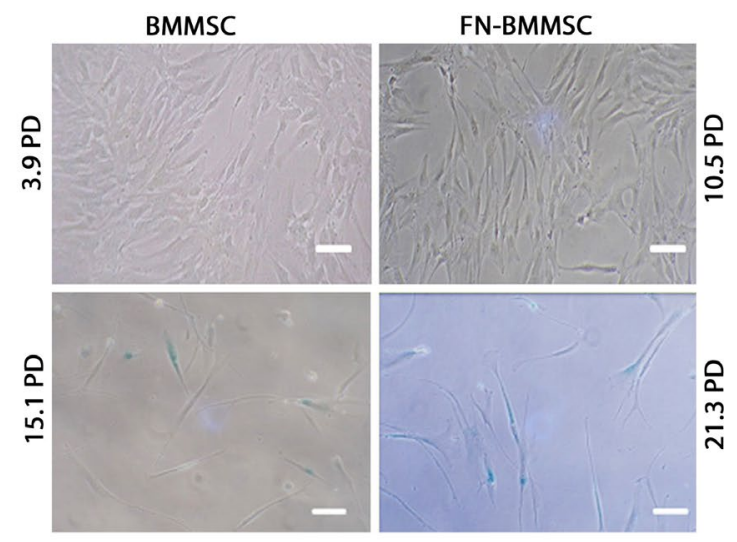

\begin{tabular}{|l|c|}
\hline \multicolumn{1}{|c|}{ Cell population } & $\begin{array}{c}\text { Cells staining for } \\
\beta \text {-galactocidase }\end{array}$ \\
\hline BMMSC - 12.7 PD & $3.0 \%$ \\
BMMSC - 15.1 PD & $58.7 \%$ \\
FN - BMMSC - 17.6 PD & $2.4 \%$ \\
FN - BMMSC - 20.4PD & $74 \%$ \\
\hline
\end{tabular}

Fig. 2. Comparison of MSC characteristics of commercial BMMSCs and the same cells selected by preferential fibronectin adherence to select a more immature cell population, FN-BMMSC. (A) Following culture expansion FN-BMMSCs demonstrated an ability to proliferate to approximately 20 PD whilst proliferation of parent BMMSCs started to slow at approximately 13 PDs. (B) RT-PCR demonstrated the expression of all classical MSC markers by both populations; an increase in the embryonic marker Nanog was observed for FN-BMMSC. (C) Culture expansion induced senescence within both cell populations as determined by blue cells staining for $\beta$-galactosidase; senescence developed at a later PD for FN-BMMSC cells. White scale bars represent $100 \mu \mathrm{M}$. 


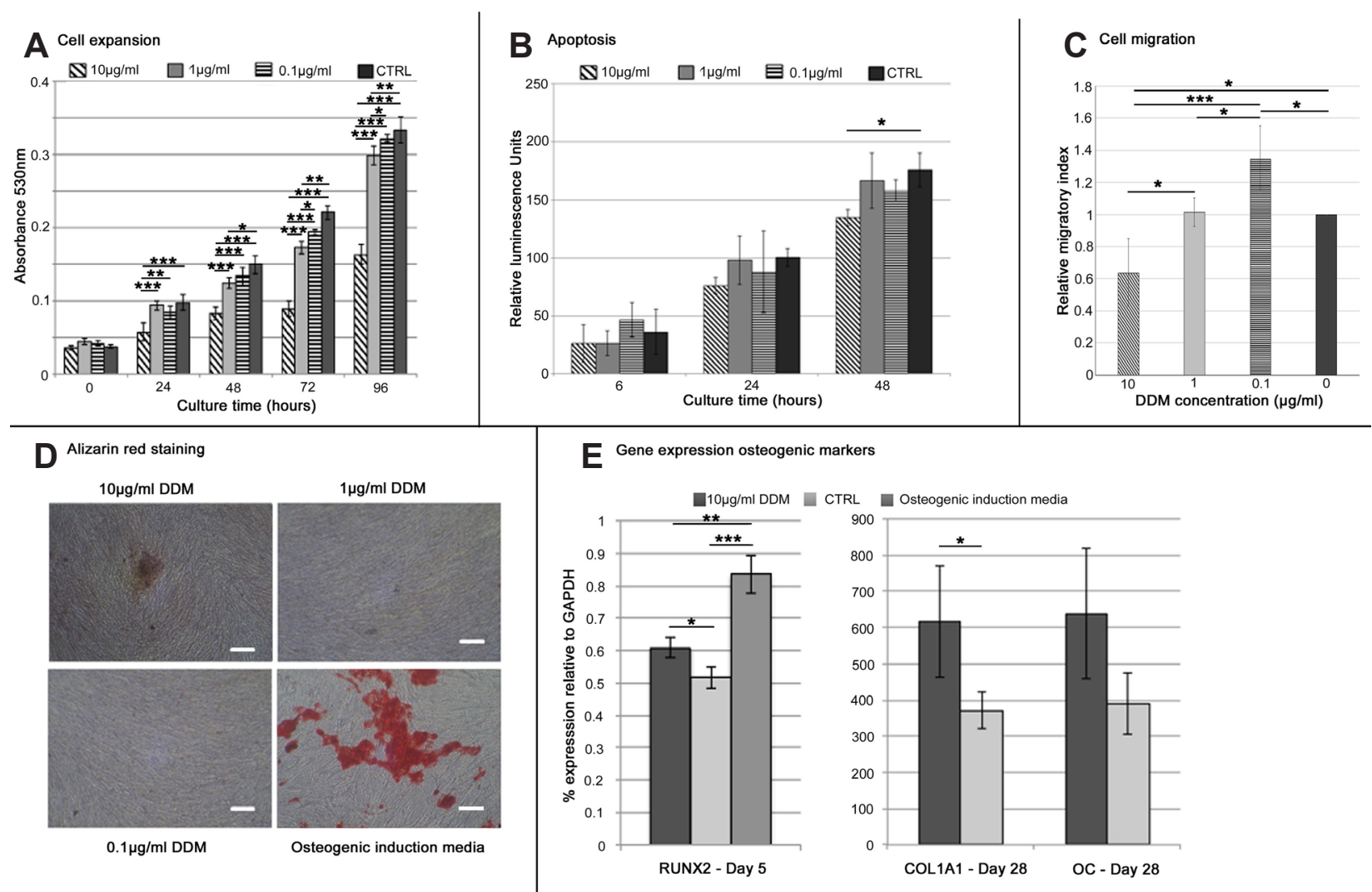

Fig. 3. (A) DDM reduced the expansion of FM-BBMSCs, which appeared to be dose dependent, with significant reduction for cells supplemented with $10 \mu \mathrm{g} / \mathrm{mL}$ compared to non-supplemented cells observed at all time points and significance obtained for cells with $1 \mu \mathrm{g} / \mathrm{mL}$ DDM after $48 \mathrm{~h}$. (B) $10 \mu \mathrm{g} / \mathrm{mL}$ DDM was the only concentration observed to significantly inhibited cell apoptosis as demonstrated by a reduction in the fluorescence read-out. (C) $10 \mu \mathrm{g} / \mathrm{mL}$ DDM also inhibited the migration of cells through a collagen matrix, whilst $0.1 \mu \mathrm{g} / \mathrm{mL}$ DDM promoted cell migration, compared to the non-supplemented control. (D) $10 \mu \mathrm{g} / \mathrm{mL}$ DDM supplementation was sufficient to induce deposition of mineralised nodules by the FM-BMMSCs as visualised by Alizarin Red staining and (E) the significant increase in gene expression for RunX2, Col1A1 and OC as determined by qPCR. Osteogenic induction media represented a positive control. $\mathrm{n}=3$ for all assays identifying cellular behaviour. ${ }^{*}=p<0.05,{ }^{* *}=p<0.01,{ }^{* * *}=p<0.001$. White scale bars represent $100 \mu \mathrm{m}$.

2011) CD105, CD90, CD73 and CD146, embryonic marker Oct4 and were negligible for haemopoietic markers CD34, CD45 (Fig 1B). The selection of more immature cells was indicated by an increased proliferative lifespan for FN-BMMSCs, which achieved $>17$ PDs in long-term culture (Fig. 2A), with $75 \%$ of cells observed as senescent at 20.4 PDs (Fig. 2C); by comparison proliferation of BMMSCs slowed to $<0.5 \mathrm{PD}$ at $12 \mathrm{PD}$ and demonstrated $58.7 \%$ senescent cells at 15.1 PD. In addition, FNBMMSCs expressed the embryonic stem cell marker Nanog (Mafi et al., 2011), which was perceived as less pronounced in BMMSCs (Fig. 2B), indicating that cells expressing an immature MSC phenotype remained following fibronectin selection.

\section{Influence of DDM on FN-BMMSC cell behaviour} FN-BMMSCs supplemented with $10 \mu \mathrm{g} / \mathrm{mL}$ DDM significantly reduced cell expansion, apoptosis, cell migration (Fig. 3A-C) and was the minimal concentration able to induce formation of mineralising nodules (Fig. 3D), confirmed by increased gene expression of osteogenic markers RunX2, Col 1A1 and OC (Fig. 3E). Lower concentrations of 0.1 and $1 \mu \mathrm{g} / \mathrm{mL}$ DDM failed to produce an osteogenic response, reduced cell expansion to a lesser extent, albeit statistically significant at later time points, and had no effect on apoptosis. When the influence of DDM was assessed on cell migration, an inverse dose effect was observed. $0.1 \mu \mathrm{g} / \mathrm{mL}$ DDM stimulated migration of cells through the collagen matrix, whilst no influence in cell migration was observed in the presence $10 \mu \mathrm{g} / \mathrm{mL}$ DDM.

\section{Influence of fractionating growth factors from DDM using heparin affinity chromatography} Growth factors were fractionated from DDM by virtue of their affinity to heparin (Fig. 4). $280 \mathrm{~nm}$ absorbance elution profiles indicated that the majority of the DDM constituents failed to bind to the column, passing into the flow through (FT) eluent. Consistent with the low concentration of growth 
factors quantified in DDM, a small eluting peak was observed in fraction EL1 and minimal protein was detected in EL2 (Fig. 4B). ELISAs were performed, as a within assay triplicate, on one occasion (due to limitation of material) but indicated that over half of the BMP-2 and approximately $21.6 \%$ of TGF- $\beta 1$ was present in the FT fraction (Fig. 3C). Western blot analysis of the FT demonstrated both biglycan and decorin as present (Fig. 4D). Insufficient material prevented similar analysis of biglycan and decorin in EL1 and EL2. Approximately $36 \%$ of total TGF- $\beta 1$ present in DDM bound heparin, eluting in EL2, whilst approximately $7 \%$ of BMP-2 was present in EL1 and EL2 combined (Fig. 4C).
Whilst total fractionation of growth factors was not achieved, fractionation influenced activity on FM-BMMSCs (Fig. 5; $n=3$ for all analysis on cell behaviour). Compared to supplementation with whole DDM, constituents in eluted fractions appeared to increase cell expansion to levels approaching rates observed for non-supplemented cells, although a statistically significant difference was achieved when comparing whole DDM with EL1 (Fig. 5A). EL1 and EL2 demonstrated similar expansion rates to those observed for non-supplemented cells (Fig. 5A). Compared with whole DDM, fractionated samples also had a reduced osteogenic potential as demonstrated by a lack of stimulation of RunX2 gene
A

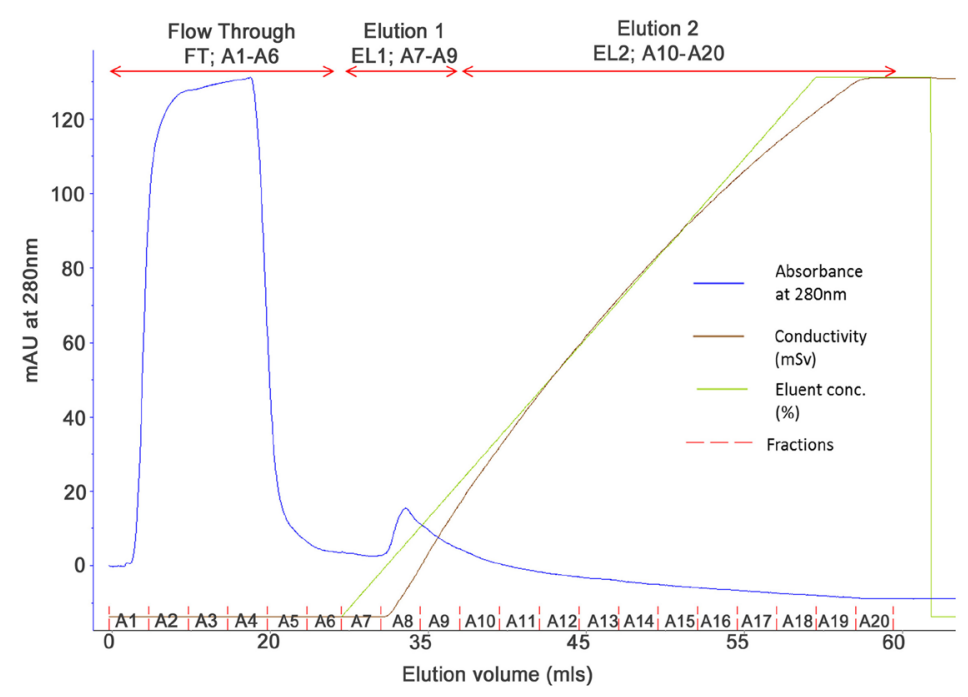

B

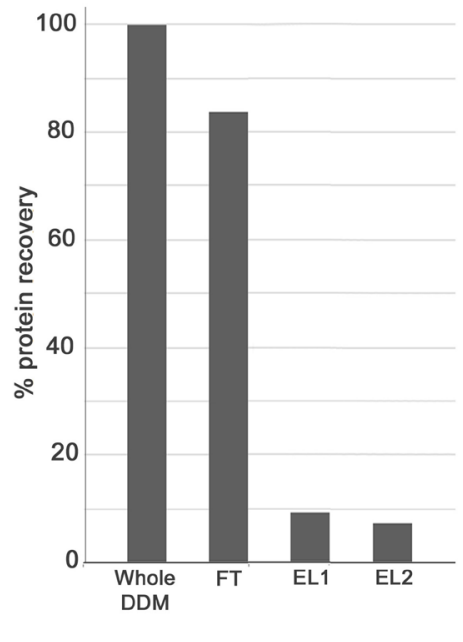

C

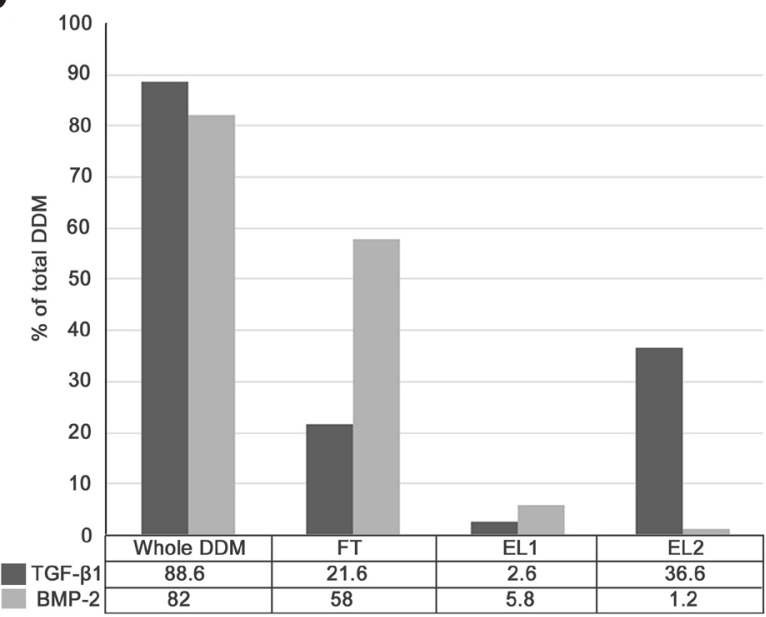

D

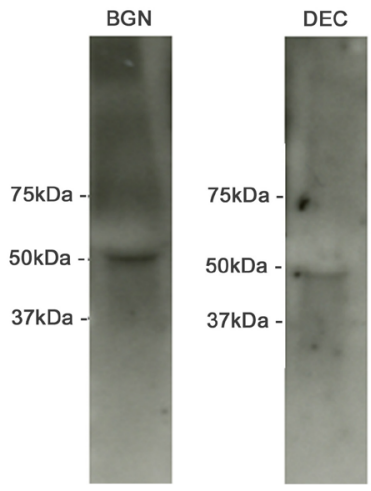

Fig. 4. Fractionation of growth factors using heparin affinity chromatography. (A) DDM was applied to heparin column and based on protein elution profiles, measuring $280 \mathrm{~nm}$ absorbance, eluting fractions were pooled to produced non-binding flow through (FT) fraction and fractions with increasing binding potential of EL1 and EL2. (B) Protein concentration was measured for each fraction and expressed as a percentage of the whole DDM, indicating low level binding of growth factors to the column, consistent with the low concentration levels of growth factors present in DDM. (C) Growth factors in each fraction were estimated using ELISA (performed in triplicate on two separate occasions; $\mathrm{n}=2$ due to insufficient material) and (D) the presence of biglycan and decorin confirmed by Western blot analysis using the appropriate primary antibodies. 

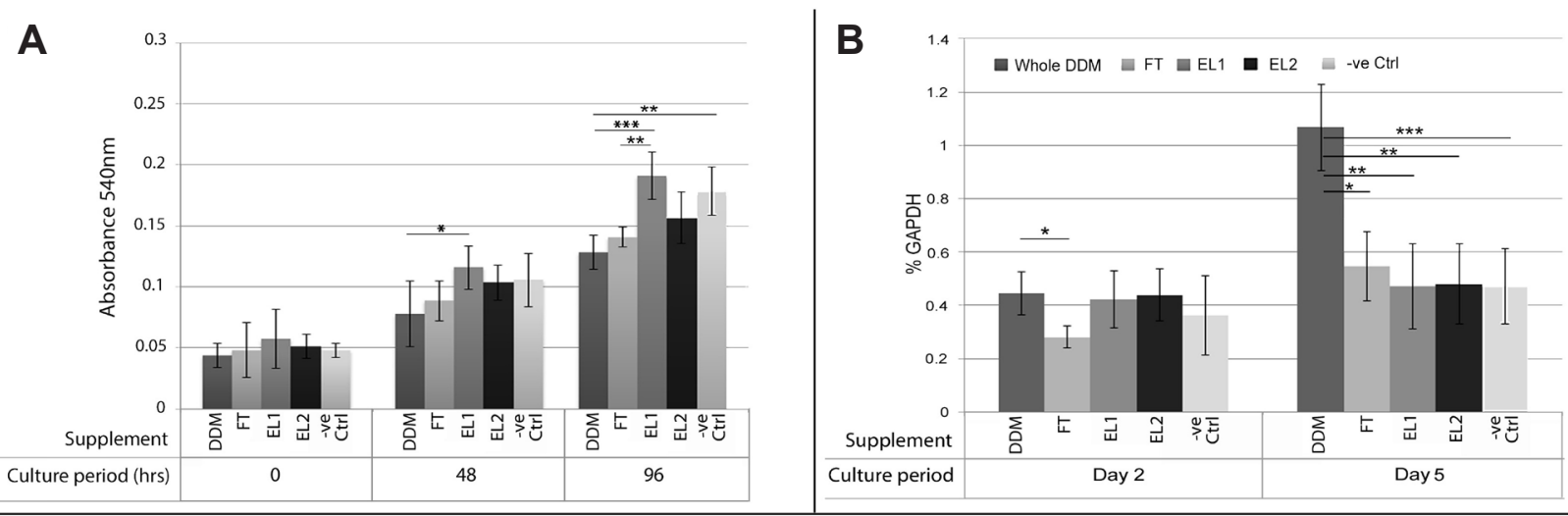

C
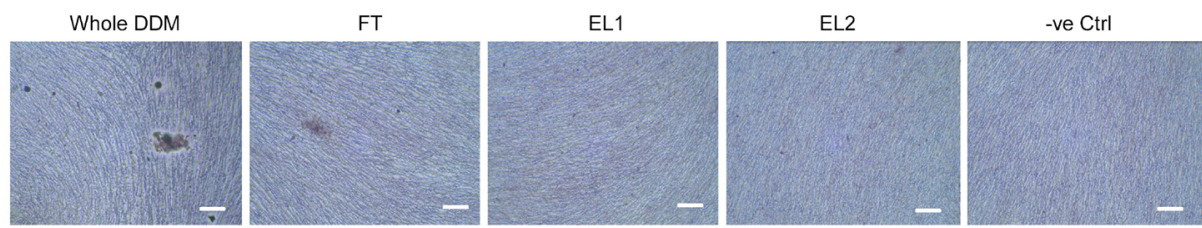

Fig. 5. The influence of fractions following heparin affinity chromatography on FM-BMMSCs. (A) All fractions appeared abolish the observed influence of whole DDM in decreasing cell expansion when compared to non-supplemented control cells, with statistical significance achieved of a higher cell expansion observed for cells supplement with EL1 compared with whole DDM. (B) Whole DDM increased the gene expression of RunX2 in FM-BMMSCs. For all fractions no increase in RunX2 was observed. (C) Following continued culture in the presence of the fractionated samples to $28 \mathrm{~d}$, small nodules with faint staining for Alizarin Red were observed for FT fraction, whilst no mineralising nodule formation was observed for EL1 and EL2. Supplementation with whole DDM demonstrated reproducible results compared to Fig. 2. All cell based assays were performed in triplicate on three separate occasions. ${ }^{*}=p<0.05,{ }^{* *}=p<0.01,{ }^{* * *}$ $=p<0.001$. White scale bars represent $100 \mu \mathrm{m}$.

expression (Fig. 5B) and no or weak mineralised nodule formation, visualised by Alizarin red (Fig. $5 C)$.

\section{Immuno-precipitation of biglycan and decorin from DDM}

Western blot analysis confirmed the single depletion of biglycan or decorin from the DDM (-BGN and - DCN respectively). Dual depletion of both decorin and biglycan from DDM was also achieved (-BGN/ $\mathrm{DCN})$. Analysis of the immuno-precipitated products $(+\mathrm{BGN},+\mathrm{DCN}$ and $+\mathrm{BGN} / \mathrm{DCN})$ confirmed the coprecipitation of TGF- $\beta 1$, which was not detected in the immuno-depleted DDM counterparts (Fig. 6A). Immuno-depleted $-\mathrm{BGN}$ or $-\mathrm{DCN}$ abolished the inhibitory effect whole DDM produced on cell expansion (observed when DDM is compared with non-supplemented control (Fig. 6B)). Immunoprecipitated $+\mathrm{BGN}$ and $+\mathrm{DCN}$ increased cell expansion compared to the non-supplemented control. Immuno-depletion for-BGN/DCN produced results similar to DDM, whilst the immunoprecipitated product $+\mathrm{BGN} / \mathrm{DCN}$ produced cell expansion rates similar to the non-supplemented control. This study also considered the effect of immuno-precipitation on osteogenic potential as judged by gene expression for RunX2 (Fig. 6C) and deposition of mineralising nodules staining with
Alizarin Red (Fig. 6D). Immuno-depleted-BGN and dual depletion for $-\mathrm{BGN} / \mathrm{DCN}$ abolish osteogenic potential; immuno-precipitated +BGN or +BGN/ DCN produced an osteogenic effect, albeit less than that observed for whole DDM; immuno-depleted -DCN slightly reduced osteogenic potential, and + DCN failed to induce either RunX2 expression or deposition of mineralising nodules.

\section{Discussion}

In vivo, dentine matrix components have been observed to promote mineralised dentine tissue repair within the tooth (Reis-Filho et al., 2012; Chun et al., 2011) and in promoting bone repair (de Oliveira et al., 2013; Gomes et al., 2008). DDM can thus be described to represent a physiologically optimised model matrix for promoting osteogenic signalling. A major aim of this study was to quantify in DDM the physiological concentrations of potential candidate growth factors recognised to act synergistically to elicit osteogenic potency (Kanczler et al., 2010; Tachi et al., 2011; Simmons et al., 2004). Notably TGF- $\beta 1$ DDM was found to be the most abundant growth factor $(15.6 \mathrm{ng} / \mathrm{mg})$, with levels more than double those identified for BMP-2, FGF, PDGF and VEGF. The molecular weight of TGF- $\beta 1$ ( $52 \mathrm{kDa})$ suggests 


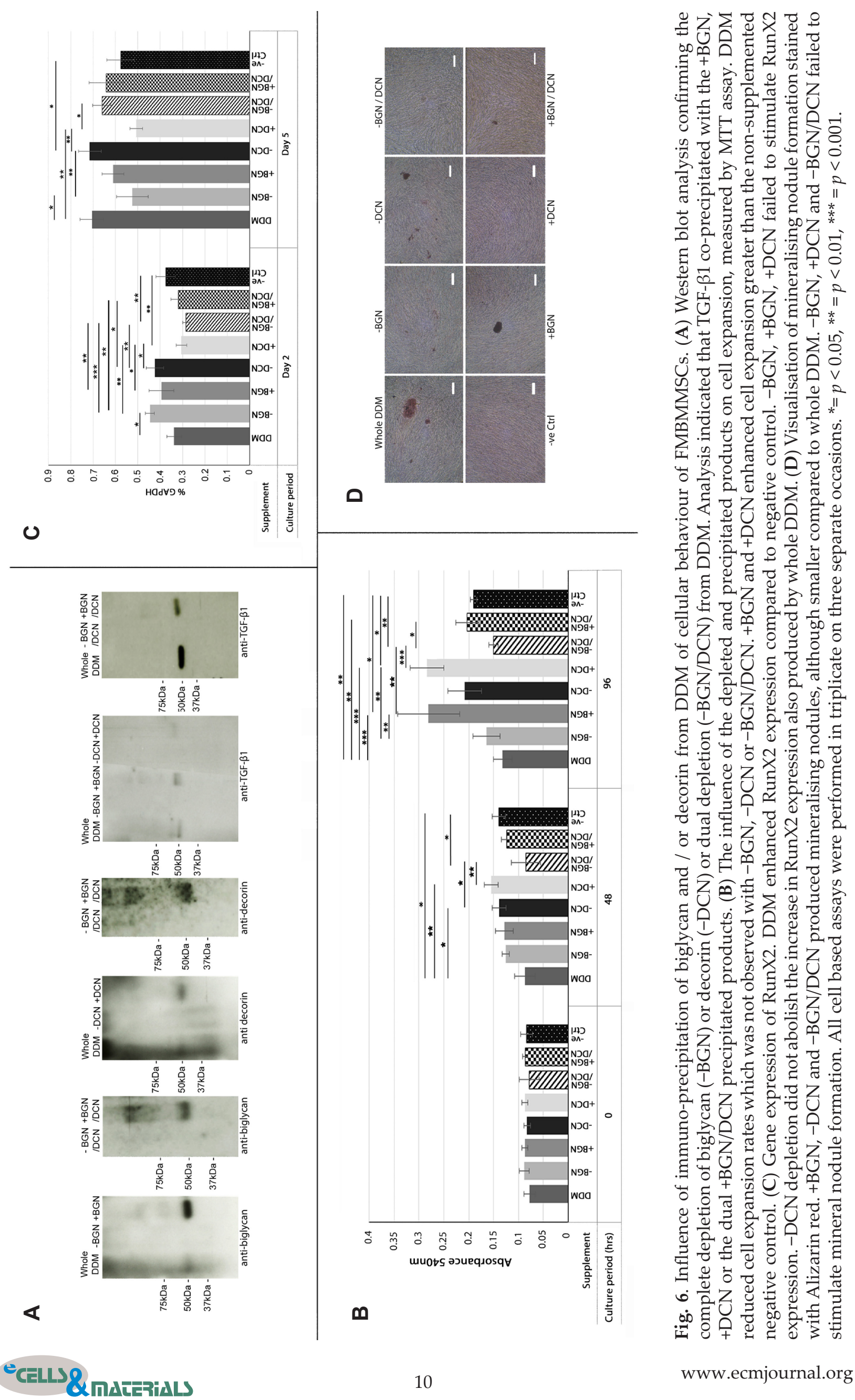


it is present as the unprocessed precursors (Gentry et al., 1988), although this form is predicted to be biologically active (Baillie et al., 1996). TGF- $\beta 1$ can induce new bone formation when injected into critical size defects (Blom et al., 2001), where it acts co-operatively with BMPs to induce osteogenic differentiation (Lee et al., 2003; Lee et al., 2000). This is consistent with the observation that both growth factors can activate independently RunX2, although only BMP-2 activates the osteogenic pathway by Dlx5 expression (Lee et al., 2003). TGF- $\beta$ can also induce BMP synthesis in the osteoprogenitor cells (Bostrom, 1998). TGF- $\beta 1$ also signals synergistically with growth factors such as FGFs (Mansukhani et al., 2000) and IGFs (Hughes et al., 2006), where collectively they have been attributed prominent roles in the migration of MSC and macrophages to the wound healing site, to induce MSC proliferation and stimulate the production of a collagenous osteoid matrix. Other synergistic signalling networks are also observed in DDM. VEGF is recognised as an important mitogen regulating budding of new endothelial cells for revascularisation (Dimitriou et al., 2005). Its action has been shown to be enhanced by PDGF and basic FGF (Al-Aql et al., 2008), which are also identified in DDM in the present study.

Within our study, $10 \mu \mathrm{g} / \mathrm{mL}$ of DDM was the minimal concentration capable of inducing an osteogenic response, which correlated with a decreased cell proliferation. At this concentration, DDM significantly reduced apoptotic cell numbers, indicating a role for promoting cell survival. However, at low concentrations of $0.1 \mu \mathrm{g} / \mathrm{mL}$, DDM presented a chemo-attractant role, inducing migration of cells through a collagen matrix, whilst $10 \mu \mathrm{g} / \mathrm{mL}$ inhibited cell migration. Similar actions for DDM preparations have been noted for dental pulp stem cells (Lee et al., 2015; Gonçalves et al., 2016; Liu et al., 2016) although it should be noted that for these studies the demineralised dentine extract was prepared using different protocols that varied around the theme of demineralising the mineralised tissue and thus would lead to DDM of different composition to that identified in the present study. As a direct comparison, for DDM prepared following the same protocol (Lee et al., 2015), the up-regulation of bone forming markers in dental pulp stem cells has been shown to be induced with DDM at $1 \mu \mathrm{g} /$ $\mathrm{mL}$, with $10 \mu \mathrm{g} / \mathrm{mL}$ DDM significantly increasing cell proliferation, thus highlighting differential effects of DDM on cells from different tissue sources. Within the culture media in our study, $10 \mu \mathrm{g} / \mathrm{mL}$ equates to approximately $110 \mathrm{pg} / \mathrm{mL}$ of TGF- $\beta 1$ and $50 \mathrm{pg} / \mathrm{mL}$ of BMP-2, FGF and PDGF. One hundred-fold lower concentrations induce MSC migration. These levels are multiple times lower than the plethora of in vitro studies investigating one or two growth factors. The results emphasise a strong therapeutic potential for these physiological levels of growth factors when considering placement of DDM in the following bone healing site scenario in vivo. DDM first promotes the migration of BMMSCs along a chemo-attractant gradient of increasing concentration of stimulatory factors. Migratory potential is subsequently negated when the cell reaches the wound healing site where the higher concentration of DDM enhances BMMSC survival, expansion and subsequent osteogenic differentiation. The present study also indicated how the ratio of growth factors, operating via various additive or opposing regulatory signalling pathways, are important in producing an overall osteogenic effect. When DDM was fractionated, although heparin binding fractions contained TGF- $\beta 1$ and BMP-2 (EL1 and EL2), supplementation of FNBMMSCs with these fractions failed to induce an osteogenic effect. Unbound DDM (FT), also contained reduced levels of TGF- $\beta 1$ and BMP-2 $(21.6 \%$ and $58 \%$ of total present in whole DDM), and also produce less intensely stained mineralising nodules.

This study additionally investigated the bioactive contribution of decorin and biglycan to the DDM, as matrix components able to bind TGF- $\beta 1$ and BMP-2 (Baker et al., 2009). Indeed, immuno-precipitation of either biglycan or decorin from the DDM was accompanied by the co-precipitation of TGF- $\beta 1$. Our results are notable for indicating a strong osteogenic inductive role for biglycan, but not for decorin. DDM depletion for biglycan abolished osteogenic differentiation, but precipitated biglycan supported an osteogenic response by the FN-BMMSC cells. Decorin-depleted DDM produced an osteogenic response, but precipitated decorin did not. These observations mirror knock-out studies assessing roles for biglycan and decorin. In vivo, biglycan ${ }^{-/-}$mice experience reduced bone growth and skeletal mass compared to wild-type animals (Xu et al., 1998), in addition to reduced callus size and less woven bone at the fracture site (Berendsen et al., 2014). Decorindepletion in vivo did not affect bone quality, although double depletion of both decorin and biglycan produced mice with severe bone defects (Young et al., 2006). In vitro, transfection of MC3T3-E1 cells with biglycan enhances matrix mineralisation, whilst mineralisation is depressed in biglycan-KO cells (Parisuthiman et al., 2005). These studies have led to the proposal that biglycan possesses modulatory effects on growth factor activities by sequestering TGF- $\beta 1$ and preventing over-activation of signalling (Bi et al., 2005), and enhancing BMP-4 (Chen et al., 2004) and BMP-2 signalling pathways (Berendsen et al., 2011). Furthermore, biglycan has been reported to increase RunX2 transcription as a pericellular ligand binding participant in Wnt signalling (Nikitovic et al., 2012; Nastase et al., 2012).

Within this study, precipitated biglycan or decorin also enhanced cell expansion greater than the nonsupplemented control, which may also be attributable to co-precipitating TGF- $\beta 1$. This result further supports proposed roles for biglycan synthesis in directing proliferation and initiation of osteoblast differentiation in bone derived MSCs/precursor cells (Waddington et al., 2003b; Roberts et al., 2008). 
However, the cellular influence of biglycan is likely to be dependent on growth factor concentration and cross-talk from other signalling pathways, and this is demonstrated in the present study. Cell expansion in the presence of both precipitated biglycan / decorin combined, where TGF- $\beta 1$ concentration would be higher, was similar to non-supplemented control levels. Supplementation with whole DDM, (higher levels of TGF- $\beta 1$, again), reduces cell expansion compared with the control. Collectively, these results highlight the complex signalling milieu of bone healing. While indicating osteogenic roles for growth factors, which necessitates TGF- $\beta 1$ co-operative action with BMP-2 and other growth factors, there is also a necessary requirement for other matrix proteins such as biglycan to enhance bioactivity.

\section{Conclusion}

This study has identified bioactive utility for DDM in facilitating cell migration, promoting cell survival, regulating proliferation and promoting osteoblast differentiation for enhanced bone repair. Analyses identified optimal growth factor combinations, with prominent roles for TGB- $\beta 1$, along with biglycan in enhancing an osteogenic response. DDM presents an attractive base for development of a graft material for augmenting bone repair, but significantly one where growth factors are present at pg levels, negating the toxicity issues and potential for ectopic mineralisation encountered in the clinical use of single recombinant forms of growth factors, such as BMP-2. Furthermore, DDM has the capacity to restore compromised signalling environments where in vivo studies have already demonstrated the potential of DDM to ameliorate delayed diabetic bone healing (Gomes et al., 2008). Levels and ratios of growth factor components are critical to its bioactivity, since fractionation or depletion of components in DDM abrogated osteogenic potential, emphasising that it is the whole DDM matrix that is prerequisite to present an optimised signalling environment to the wound healing site. Of note, DDM contains matrix proteins such as dentine sialoprotein, dentine phosphoprotein, bone sialoprotein, osteopontin, dentine matrix protein-1 and matrix extracellular phosphoglycoprotein (MEPE), with associated proposed signalling roles in the early reparative events (Smith et al., 2012); although their roles for a more comprehensive evaluation of DDM's bioactivity have yet to be verified.

\section{Acknowledgements}

The authors are grateful to the Rosetrees Trust, UK (Ref M309) for funding of this study.

\section{References}

Al-Aql ZS, Alagl AS, Graves DT, Gerstenfeld LC, Einhorn TA (2008) Molecular mechanisms controlling bone formation during fracture healing and distraction osteogenesis. J Dent Res 87: 107-118.

Arana-Chavez VE, Massa LF (2004) Odontoblasts: the cells forming and maintaining dentine. Int J Biochem Cell Biol 36: 1367-1373.

Axelrad TW, Einhorn TA (2009) Bone morphogenetic proteins in orthopaedic surgery. Cytokine Growth Factor Rev 20: 481-488.

Baillie R, Coombes RC, Smith J (1996) Multiple forms of TGF $\beta 1$ in breast tissues: a biologically active form of the small latent complex of TGF $\beta 1$. Eur J Cancer 32A: 1566-1573.

Baker SM, Sugars RV, Wendel M, Smith AJ, Waddington RJ, Cooper PR, Sloan AJ (2009) TGFbeta/ extracellular matrix interactions in dentin matrix: a role in regulating sequestration and protection of bioactivity. Calcif Tissue Int 85: 66-74.

Berendsen AD, Fisher LW, Kilts TM, Owens RT, Robey PG, Gutkind JS, Young MF (2011) Modulation of canonical Wnt signaling by the extracellular matrix component biglycan. Proc Natl Acad Sci USA 108: 17022-17027.

Berendsen AD, Pinnow EL, Maeda A, Brown AC, McCartney-Francis N, Kram V, Owens RT, Robey PG, Holmbeck K, de Castro LF, Kilts TM, Young MF (2014) Biglycan modulates angiogenesis and bone formation during fracture healing. Matrix Biol 35: 223-231.

Bi Y, Stuelten CH, Kilts T, Wadhwa S, Iozzo RV, Robey PG, Chen XD, Young MF (2005) Extracellular matrix proteoglycans control the fate of bone marrow stromal cells. J Biol Chem 280: 30481-30489.

Blom EJ, Klein-Nulend J, Yin L, van Waas MA, Burger EH (2001) Transforming growth factor-beta1 incorporated in calcium phosphate cement stimulates osteotransductivity in rat calvarial bone defects. Clin Oral Implants Res 12: 609-616.

Bostrom MP (1998) Expression of bone morphogenetic proteins in fracture healing. Clin Orthop Relat Res 355: S116-123.

Casagrande L, Demarco FF, Zhang Z, Araujo FB, Shi S, Nör JE (2010) Dentin-derived BMP-2 and odontoblast differentiation. J Dent Res 89: 603-608.

Chen FM, Zhang M, Wu ZF (2010) Toward delivery of multiple growth factors in tissue engineering. Biomaterials 31: 6279-6308.

Chen XD, Fisher LW, Robey PG, Young MF (2004) The small leucine-rich proteoglycan biglycan modulates BMP-4-induced osteoblast differentiation. FASEB J 18: 948-958.

Chun SY, Lee HJ, Choi YA, Kim KM, Baek SH, Park HS, Kim JY, Ahn JM, Cho JY, Cho DW, Shin HI, Park EK. (2011) Analysis of the soluble human tooth proteome and its ability to induce dentin/tooth regeneration. Tissue Eng Part A 17: 181-191.

de Oliveira GS, Miziara MN, Silva ER, Ferreira EL, Biulchi AP, Alves JB (2013) Enhanced bone formation 
during healing process of tooth sockets filled with demineralized human dentine matrix. Aust Dent J 58: 326-332.

Dimitriou R, Tsiridis E, Giannoudis PV (2005) Current concepts of molecular aspects of bone healing. Injury 36: 1392-13404.

Finkelman RD, Mohan S, Jennings JC, Taylor AK, Jepsen S, Baylink DJ (1990) Quantitation of growth factors IGF-I, SGF/IGF-II, and TGF-beta in human dentin. J Bone Miner Res 5: 17-23.

Geiger F, Bertram H, Berger I, Lorenz H, Wall O, Eckhardt C, Simank HG, Richter W (2005) Vascular endothelial growth factor gene-activated matrix (VEGF165-GAM) enhances osteogenesis and angiogenesis in large segmental bone defects. J Bone Miner Res 20: 2028-2035.

Gentry LE, Lioubin MN, Purchio AF, Marquardt $\mathrm{H}$ (1988) Molecular events in the processing of recombinant type 1 pre-pro-transforming growth factor beta to the mature polypeptide. Mol Cell Biol 8: 4162-4168.

Gomes MF, Destro MF, Banzi EC, Vieira EM, Morosolli AR, Goulart Md (2008) Optical density of bone repair after implantation of homogenous demineralized dentin matrix in diabetic rabbits. Braz Oral Res 22: 275-280.

Gonçalves LF, Fernandes AP, Cosme-Silva L, Colombo FA, Martins NS, Oliveira TM, Araujo TH, Sakai VT (2016) Effect of EDTA on TGF- $\beta 1$ released from the dentin matrix and its influence on dental pulp stem cell migration. Braz Oral Res 30: e131. doi: 10.1590/1807-3107BOR-2016.vol30.0131

Hughes FJ, Turner W, Belibasakis G, Martuscelli G (2006) Effects of growth factors and cytokines on osteoblast differentiation. Periodontol 2000 41: 48-72.

Jágr M, Eckhardt A, Pataridis S, Mikšík I (2012) Comprehensive proteomic analysis of human dentine. Eur J Oral Sci 120: 259-268.

Jones PH, Watt FM (1993) Separation of human epidermal stem cells from transit amplifying cells on the basis of differences in integrin function and expression. Cell 73: 713-24.

Kanczler JM, Ginty PJ, White L, Clarke NMP, Howdle SM, Shakesheff KM, Oreffo ROC (2010) The effect of the delivery of vascular endothelial growth factor and bone morphogenic protein- 2 to osteoprogenitor cell populations on bone formation. Biomaterials 31: 1242-1250.

Lee CP, Colombo JS, Ayre WN, Sloan AJ, Waddington RJ (2015) Elucidating the cellular actions of demineralised dentine matrix extract on a clonal dental pulp stem cell population in orchestrating dental tissue repair. J Tissue Eng 6: 1-13.

Lee K, Silva EA, Mooney DJ (2011) Growth factor delivery-based tissue engineering: general approaches and a review of recent developments. J R Soc Interface 55: 153-170.

Lee KS, Kim HJ, Li QL, Chi XZ, Ueta C, Komori T, Wozney JM, Kim EG, Choi JY, Ryoo HM, Bae SC (2000) Runx2 is a common target of transforming growth factor beta1 and bone morphogenetic protein
2, and cooperation between Runx2 and Smad5 induces osteoblast-specific gene expression in the pluripotent mesenchymal precursor cell line C2C12. Mol Cell Biol 20: 8783-8792.

Lee MH, Kim YJ. Kim HJ, Park HD, Kang AR, Kyung HM, Sung JH, Wozney JM, Kim HJ, Ryoo HM (2003) BMP-2-induced Runx2 expression is mediated by Dlx5, and TGF-beta 1 opposes the BMP-2-induced osteoblast differentiation by suppression of Dlx5 expression. J Biol Chem 278: 34387-34394.

Liu G, Xu G, Gao Z, Liu Z, Xu J, Wang J, Zhang C, Wang $S$ (2016) Demineralized dentin matrix induces odontoblastic differentiation of dental pulp stem cells. Cells Tissues Organs 201: 65-76.

Mafi P, Hindocha S,Mafi R, Griffin M, Khan WS (2011) Adult mesenchymal stem cells and cell surface characterization: a systematic review of the literature. Open Orthop J 5, (Suppl 2-M4): 253-260.

Mansukhani A, Bellosta P, Sahni M, Basilico C (2000) Signaling by fibroblast growth factors (FGF) and fibroblast growth factor receptor 2 (FGFR2)activating mutations blocks mineralization and induces apoptosis in osteoblasts. J Cell Biol 149: 12971308.

Nastase MV, Young MF, Schaefer L (2012) Biglycan: a multivalent proteoglycan providing structure and signals. J Histochem Cytochem 60: 963-975.

Nikitovic D, Aggelidakis J, Young MF, Iozzo RV, Karamanos NK, Tzanakakis GN (2012) The biology of small leucine-rich proteoglycans in bone pathophysiology. J Biol Chem 287: 33926-33933.

Parisuthiman D, Mochida Y, Duarte WR, Yamauchi M (2005) Biglycan modulates osteoblast differentiation and matrix mineralization. J Bone Miner Res 20: 1878-1886.

Park ES, Cho HS, Kwon TG, Jang SN, Lee SH, An CH, Shin HI, Kim JY, Cho JY (2009) Proteomics analysis of human dentin reveals distinct protein expression profiles. J Proteome Res 8: 1338-1346.

Reis-Filho CR, Silva ER, Martins AB, Pessoa FF, Gomes PV, de Araújo MS, Miziara MN, Alves JB (2012). Demineralised human dentine matrix stimulates the expression of VEGF and accelerates the bone repair in tooth sockets of rats. Arch Oral Biol 57: 469-476.

Roberts HC, Moseley R, Sloan AJ, Youde SJ, Waddington RJ (2008) Lipopolysaccharide alters decorin and biglycan synthesis in rat alveolar bone osteoblasts: consequences for bone repair during periodontal disease. Eur J Oral Sci 116: 207-216.

Roberts TT, Rosenbaum AJ (2012) Bone grafts, bone substitutes and orthobiologics: the bridge between basic science and clinical advancements in fracture healing. Organogenesis 8: 114-124.

Roberts-Clark DJ, Smith AJ (2000) Angiogenic growth factors in human dentine matrix. Arch Oral Biol 45: 1013-1016.

Sadaghiani L, Gleeson HB, Youde SJ, Waddington RJ, Lynch CD, Sloan AJ (2016). Growth Factor 
Liberation and DPSC Response Following Dentine Conditioning. J Dent Res 95: 1298-1307.

Simmons CA, Alsberg E, Hsiong S, Kim WJ, Mooney DJ (2004) Dual growth factor delivery and controlled scaffold degradation enhance in vivo bone formation by transplanted bone marrow stromal cells. Bone 35: 562-569.

Smith AJ, Cassidy N, Perry H, Bègue-Kirn C, Ruch JV, Lesot H (1995) Reactionary dentinogenesis. Int J Dev Biol 391: 273-280

Smith AJ, Scheven BA, Takahashi Y, Ferracane JL, Shelton RM, Cooper PR (2012) Dentine as a bioactive extracellular matrix. Arch Oral Biol 57: 109-121.

Tachi K, Takami M, Sato H, Mochizuki A, Zhao B, Miyamoto $\mathrm{Y}$, Tsukasaki H, Inoue T, Shintani S, Koike T, Honda Y, Suzuki O, Baba K, Kamijo R (2011) Enhancement of bone morphogenetic protein2-induced ectopic bone formation by transforming growth factor- $\beta 1$. Tissue Eng Part A 17: 597-606.

Waddington RJ, Hall RC, Embery G, Lloyd DM (2003a) Changing profiles of proteoglycans in the transition of predentine to dentine. Matrix Biol 22: 153-161.

Waddington RJ, Roberts HC, Sugars RV, Schönherr E (2003b) Differential roles for small leucine-rich proteoglycans in bone formation. Eur Cell Mater 6: 12-21.
Xu T, Bianco P, Fisher LW, Longenecker G, Smith E, Goldstein S, Bonadio J, Boskey A, Heegaard AM, Sommer B, Satomura K, Dominguez P, Zhao C, Kulkarni AB, Robey PG, Young MF (1998) Targeted disruption of the biglycan gene leads to an osteoporosis-like phenotype in mice. Nat Genet 20: 78-82.

Young MF, Bi Y, Ameye L, Xu T, Wadhwa S, Heegaard A, Kilts T, Chen XD (2006) Small leucine-rich proteoglycans in the aging skeleton. J Musculoskelet Neuronal Interact 6: 364-365.

Yu Y, Wang L, Yu J, Lei G, Yan M, Smith G, Cooper PR, Tang C, Zhang G, Smith AJ (2014) Dentin matrix proteins (DMPs) enhance differentiation of BMMSCs via ERK and P38 MAPK pathways. Cell Tissue Res 356: 171-182.

Zara JN, Siu RK, Zhang X, Shen J, Ngo R, Lee M, Li W, Chiang M, Chung J, Kwak J, Wu BM, Ting K, Soo C (2011) High doses of bone morphogenetic protein 2 induce structurally abnormal bone and inflammation in vivo. Tissue Eng Part A 17: 1389-1399.

Editor's notes: All of the matters raised by the reviewers have been incorporated in the main text, so there is no Discussion with reviewers section for this paper.

The Scientific Editor for this paper was Juerg Gasser. 